\title{
The Ethics of Price Discrimination
}

\author{
Juan M. Elegido
}

\begin{abstract}
Price discrimination is the practice of charging different customers different prices for the same product. Many people consider price discrimination unfair, but economists argue that in many cases price discrimination is more likely to lead to greater welfare than is the uniform pricing alternative-sometimes for every party in the transaction. This article shows i) that there are many situations in which it is necessary to engage in differential pricing in order to make the provision of a product possible; and ii) that in many such situations, the seller does not obtain an above-average rate of return. It concludes that price discrimination is not inherently unfair. The article also contends that even when conditions i) and/or ii) do not obtain, price discrimination is not necessarily unethical. In itself, the fact that some people get an even better deal than do others does not entail that the latter are wronged.
\end{abstract}

$\mathrm{I}^{\mathrm{T}}$

T HAS OFTEN BEEN SAID that the easiest way to spoil a plane trip is to ask

your seatmate how much she paid for her ticket. You might well find that while you (or your employer) paid $\$ 1,100$, your seatmate was making the same trip, with the same comfort, for only $\$ 180$. Also, if you tried to buy a laptop computer from the manufacturer's website and identified yourself as a small-business owner, you might be informed that the price was, say, $\$ 1,200$. However, if you visited the same manufacturer's site under different identities, you might find that the price of the same system was $\$ 1,050$ for health care organizations, while for local governments it was only \$1,000 (cf. McWilliams, 2001). And these are not isolated examples. Price discrimination-although often in slightly disguised forms - is a pervasive phenomenon that affects a wide variety of products (Baumol \& Swanson, 2003). (I use the term "product" in this article to refer to both goods and services.)

Price discrimination is the practice of charging different customers different prices for the same product. It is sometimes referred to as "differential pricing" or "tiered pricing." "Dynamic pricing" and "smart pricing" are modern terms for variants of the same basic practice. The topic of price discrimination is acquiring added importance because, as we will see below, typical modern economic conditions tend to force companies to engage in it (Baumol \& Swanson, 2003), and because modern technology makes it possible to implement it in ever more refined ways (Grewal \& Compeau, 1999; Sinha, 2000).

Many people dislike price discrimination, especially when it results in their paying higher prices than do others (Campbell, 1999; Kahneman, Knetsch \& Thaler, 1986; Krugman, 2000; McCartney, 2010; Vitell, Rawwas \& Festerband, 1991). ${ }^{1}$ Some big scandals have ensued when cases of price discrimination have come to the attention of the public. Some years ago it was discovered that Amazon.com had been charging different prices to different customers for the same DVDs. This was done by quoting the same basic price to everybody but then offering different discounts to different 
customers. The retailer was forced by public pressure to discontinue the practice, promise that it would never engage again in it, and offer refunds to customers who had paid higher prices (Turow, 2005).

From the standpoint of ethical theory, price discrimination may be suspect for several reasons. Leaving aside any unsavory circumstances that might accompany the practice, such as, for instance, lack of transparency about the prices charged or the possible breaches of privacy involved in gathering information about each customer's reservation price, the fact that different customers are charged different prices may suggest that those customers who have been charged the higher prices might have been exploited through having been charged an unfair price. Further, the fact that the seller could cover its costs at a lower price could indicate that the higher prices charged to some customers are unfair. Finally, the circumstance of different people being charged different prices shows that an equal-treatment norm (if such a norm exists) has been breached.

The condemnation of price discrimination is not universal. Economists often defend it (Frank, 2006; Phlips, 1983; Varian, 1996). It also seems that many ordinary people can eventually reconcile themselves to differential pricing. Thus, for instance, most customers are aware of the widespread use of dynamic pricing by airlines; however, as many of them have learned to play the discounted fares game, the practice no longer seems to evoke the outrage it formerly did.

Price discrimination, therefore, is common in the business world (and likely to become more so), is suspect in the eyes of ethical theory, and reactions to it vary. It would seem an issue ripe for ethical analysis. However, ethicists, with very few exceptions (Marcoux, 2006), have done almost no systematic work on the topic. The purpose of this article is to begin to fill this gap in the business ethics literature. My focus will be the ethical status of the practice; I will not venture to consider potential public policy initiatives in relation to it.

I first address some definitional issues and refer to some examples of price discrimination to help give readers a better feel for the many forms the practice can take. I then present some results of the work economists have done that are relevant to an ethical study of price discrimination. Finally, I present arguments of an ethical nature to support the thesis that price discrimination in itself is not always unethical, although it may be unethical when used for certain purposes or in certain contexts.

My subject in this article is price discrimination, not the wider issue of fairness in pricing. I do not take a stand here on what it is that makes a price fair; my concern is whether charging two different prices (each of which is fair in itself) to two different people is itself unfair. ${ }^{2}$

In regard to justice in pricing, my own view-which I have defended elsewhere-is that a price is just or fair if it is the price that obtains in an open market (not necessarily a competitive one market) (Elegido, 1996, 2009). But several different theories of justice in pricing have been put forward. ${ }^{3}$ Even though I believe that my own position on this wider issue is superior to the alternatives, because of space constraints I will not defend it again in this article. At any rate, the thesis I argue for here does not depend on the correctness of my views on fair prices. The main point I put forward in this article is that if charging a certain price in a given 
transaction does not offend against whichever standard of fairness in pricing proves ultimately to be correct, or against other ethical standards, then the mere fact that the same seller sells the same good at a lower price to a different buyer will not by itself make it unethical. ${ }^{4}$

\section{INTRODUCING PRICE DISCRIMINATION}

Defining price discrimination in terms of charging different customers different prices for the same product would seem to require a definition of "the same product." When two identical laptops are sold to two buyers at the same place, on the same day, with the same warranties and the same service arrangements, it seems safe to say that "the same product" has been sold to the two buyers. On the other hand, it is far less clear that two London-New York airplane tickets for the same date, time, and aircraft, departing from and landing at the same airports but one being for a business class seat, refundable and re-routable, while the other is for and economy-class, non-refundable and non-reroutable seat, are "the same product." It would be possible to stipulate a very precise definition of the expression "the same product" for this article, but it is likely to be more productive to abstain from doing so and retain the flexibility with which it is possible to use the term in ordinary language. For the theoretical purposes of this article it will be better to demarcate the type of phenomenon studied not by reference to the question of when products are similar and when they are significantly different but rather, following on the footsteps of economists, by reference to the relation between the prices and costs of similar products.

Economists have generally accepted Stigler's proposal to stipulate that price discrimination exists when the ratio of the prices of two similar products is different from the ratio of their marginal costs (Stigler, 1987). By this test it seems clear, for instance, that the difference in price between hardcover and paperback versions of the same book often constitutes price discrimination, as typically the difference is significantly larger than the difference between the marginal costs of producing the two versions of the book (Clerides, 2004). The same test will indicate whether or not there is price discrimination when the same physical object is sold in different markets — or through different channels—at different prices. Similarly, as Stole has observed, where discrimination occurs over the provision of quality, operationalizing Stigler's definition requires using the marginal prices of different standards of quality and the associated marginal costs (Stole, 2007). It follows from Stigler's proposal that when cost differences justify price differences between apparently similar products, one should not speak of price discrimination. This is important because some cases that appear to be price discrimination can be explained by cost differentials (Lott \& Roberts, 1991).

There are two main reasons to follow Stigler's stipulative definition rather than to concentrate exclusively on cases in which different prices are charged for identical products. In the first place, demanding identity of products (to the point, at the extreme, of considering that if identical physical products are sold in two different places or on two different days they should be considered, for analytical purposes, 
different products) would reduce very significantly the practical applicability of the arguments I am about to put forward. Just consider the examples of price discrimination offered in this article and you will notice how few cases involve identical or nearly identical products. Secondly, as Marcoux (2006) argues convincingly, price discrimination thus strictly construed is not likely to be durable. As we will see in the next section, in the absence of monopoly, competition will always push toward unitary pricing. However, price discrimination understood along the wider lines of Stigler's proposal may not only be durable but also required for the survival of firms in many industries, as is shown below. In many industries, provided that there is room for some product differentiation, competition will tend to erode the profits of price discriminators but will not undermine the practice itself. The airline industry provides the best known and most accessible example of this dynamic (Mueller, 2004).

Price discrimination takes many different forms. Colleges that grant different financial aid to different students according to the student's merit and the family's financial position, effectively charging different prices to different students, practice price discrimination (McPherson \& Schapiro, 1998). Other examples of price discrimination are the discounts in prices for many services that are provided to students and senior citizens; different prices for software intended for personal or business use (Grewal \& Compeau, 1999); different prices for men's and women's haircuts, even in cases in which the haircuts are practically identical (City of New York, Department of Consumer Affairs, 1992; Liston-Heyes \& Neokleous, 2000); different subscription rates to academic journals for libraries and individual subscribers (Rosenbaum \& Ye, 1997); different prices for the same drug in different countries (Frank, 2001); different freight rates by railroads for different freight classes (Odlyzko, 2004b); and granting higher discounts to new buyers of enterprise software than to older customers who are upgrading their product (Larkin, 2008).

A very popular variant of price discrimination is that in which different versions of a product are designed in such a way that the more expensive ones will be attractive to those customers who have a greater willingness to pay higher prices. The guiding policy, as Varian (1997) has observed, is to try to make the customers sort themselves according to their willingness to pay by offering them different versions of the product, which are designed to give them incentives to do exactly that. Book publishers, for instance, first release a high-price hardcover version of a new book and only some months later release a cheaper paperback version. Those readers who are especially eager to read the book and can afford to pay the higher price will buy the hardcover version, while those who are not ready to pay the higher price (whether for lack of sufficient interest or lack of means) will buy the paperback edition later (Clerides, 2004). It is also of interest to observe that publishers delay the publication of the paperback version (that is, they make this version less attractive than they could make it) precisely in order to ensure that interested readers of means have maximum incentive to buy the hardcover version. More will be said on this issue below.

Other examples of price discrimination through versioning include offering cheaper airline tickets if the stayover includes a Saturday (business passengers, who have a higher willingness to pay, are typically loath to stay an additional weekend 
away from their families), or the ticket has been bought well in advance (business travellers usually need greater scheduling flexibility). Further examples include charging a very high amount during the introductory period of a product and later dropping the price significantly (Apple reduced the price of the iPhone from \$599 to $\$ 399$ within two months of the product's launch) (Casale, Esola \& Wojcik, 2007); regular periodic sales in stores (less price-sensitive customers prefer not to wait until the next sale) (Varian, 1980); and offering coupons or rebates (poorer customers are ready to take the extra trouble involved in redeeming the coupons or claiming the rebates; wealthier customers typically do not bother) (Chen, Moorthy \& Zhang, 2005; Howell, 1991; Narasimhan, 1984).

\section{INSIGHTS FROM ECONOMICS}

While business ethics scholars have by and large failed to give price discrimination the attention it deserves, the same cannot be said of economists. There is a very large economic literature devoted to the study of this practice and it will be useful to review here some of the main conclusions that economists have reached, especially on those points that are more relevant to an ethical assessment of discriminatory prices.

For price discrimination to be possible, some conditions must be met (Stole, 2007). First, the seller must be able to identify the reservation price of each consumer or group of consumers, or at least have reliable indicators of the reservation price. Someone's reservation price for a product is the highest price that that person is ready to pay for the product. Second, there must not be significant price competition from rival firms in relation to that product; otherwise, competitors could target groups of customers who are being charged higher prices by the price discriminator and offer them more attractive deals; the effect of that competition would be to drive all prices toward the marginal cost and make price discrimination impossible. Finally, arbitrage must not be possible; that is to say, those buyers who purchase the product at a low price must not be able to resell it at a higher price to those who are willing to pay more for it. If arbitrage is possible, the low-price buyers will have a strong incentive to compete with the original supplier and undercut its business with those customers who have a higher reservation price.

Phlips (1983: 1) summarizes the typical economist's view of price discrimination when he states that " $[\mathrm{g}]$ enerally, discriminatory prices [are] required for an optimal allocation of resources in real life situations." This statement may seem surprising as conventional economic analysis argues that normally competition should make prices equal marginal costs and that this will maximize welfare. Under contemporary conditions, however, many industries—such as pharmaceuticals, biotechnology, telecommunications, semiconductors, and software—face very high fixed costs and very low marginal costs. In such situations, setting prices at the level of marginal costs would make it impossible to recoup the original investment (and therefore would result in no investment being made and no new products being offered); consequently, price discrimination may easily result in better outcomes for everyone (Baumol \& Swanson, 2003; Levine, 2002). 
Thus, while the costs of developing a new piece of software can be extremely high, the costs of producing an additional copy of that software are insignificant. In such situations, even if a group of consumers (say, businesses) are made to pay ten times more than another group (say, students), so long as the second group is paying more than the additional cost of producing the units that are sold to them, they will be contributing to covering some of the costs of developing the software, thus making it possible for the first group to be charged a price lower than what they would have had to pay otherwise.

More generally, using fairly general assumptions (that the relevant demand curves be downward slopping, that is to say, that customers be price-sensitive) Schmalensee (1981), Varian $(1985,1992,1996)$, and Schwartz (1990) have shown that price discrimination is likely to lead to higher welfare than the uniform pricing alternative, provided that the output sold using price discrimination is larger than that which can be sold at a uniform price.

Also, Baumol and Swanson (2003) have shown that where there are substantial fixed or sunk costs and decreasing average incremental costs, and provided competition exists, if a firm's customers have different demand patterns, the firm may be unable to survive unless it adopts discriminatory prices. Besides, if the industry's entry and exit costs are low, overall the firm will earn no more than competitive profits and thus will charge the lowest prices compatible with survival. The air transport industry is a well-known example of this dynamic.

Economists have also studied the distributional effects of price discrimination. It sometimes happens that price discrimination results in higher prices for the poor (Baker, 1994; Grewal \& Compeau, 1999; Huang, 2005). Thus, for instance, people who buy retail and pay cash for drug prescriptions (typically poorer citizens) tend to pay higher prices than those covered by insurance (Frank, 2001). In relation to other products, there is much discussion of the issue, but few firm conclusions. Thus, for example, there is a continuing argument on whether or not the poor pay more for food in the United States (Ambrose, 1979; Finke, Chern \& Fox, 1997; Groom, 1966; Hayes, 2000). Speaking generally, as price discrimination redistributes income from less price-sensitive to more price-sensitive groups, and as the former are often the wealthier consumers, in many occasions, price discrimination will have positive distributional effects (Tirole, 1989).

\section{ETHICAL ISSUES IN PRICE DISCRIMINATION}

We now have to face the issue squarely: Are there reasons to believe that engaging in price discrimination is unethical? As mentioned above, many people react negatively to price discrimination, especially when it results in their being charged higher prices (Campbell, 1999; Kahneman, Knetsch \& Thaler, 1986; Krugman, 2000; McCartney, 2010; Vitell, Rawwas \& Festerband, 1991). This article investigates whether that negative reaction can be justified critically.

It may be useful to first discuss briefly a preliminary point. Some studies (e.g., Ayers, 1991, 2001; Ayers \& Siegelman, 1995) have presented evidence that women and blacks are systematically quoted higher prices in car dealerships in the US 
than are white males. Obviously, if this were a way to express contempt or dislike for blacks and women, it would constitute an especially odious unethical practice. However, Ayers and Siegelman (1995) present evidence suggesting that this is not the case. At any rate, for my present purposes, the important point is that if price discrimination constitutes a way of expressing contempt or dislike for a class of individuals (and this may well happen in some situations), it is, of course, unethical. But this will not necessarily be because there is anything inherently wrong in price discrimination itself. The wrongness of such practice can be fully accounted for by the principle that slighting a group of human beings as such (whether based on racial, ethnic, linguistic, religious, gender or any other factors) is in itself wrong. ${ }^{5}$ There is no space here to elaborate on how price discrimination could be used as an expression of contempt. The more general point, however, is important: While the thesis of this article is that price discrimination in itself need not be wrong, instances of price discrimination may become wrong by being linked to wrong purposes or attitudes. It is possible, for example, to use a smile as a means to insult somebody, but we do not conclude from this that there might be something wrong with smiling; it is simply that insulting people is wrong, however innocent the means chosen to do so might be in themselves.

If it could be shown that vulnerable groups, which are already at an economic disadvantage relative to other groups, are systematically the victims of price discrimination and that the effect of this is to worsen their already bad situation, this would raise a serious ethical issue for the businesspeople involved in such price discrimination. However, as was pointed out above in the "Insights from Economics" section, there are strong reasons to expect that overall price discrimination will tend to have positive distributional effects. The view defended in this article is that, in itself, price discrimination is a morally neutral practice that businesspeople are entitled to use if it advances their morally legitimate interests. If this view is correct but a case can be identified in which the price discrimination practiced by a given business - on its own or in combination with similar actions from other businesses-has a significant negative distributional effect and worsens the plight of a given vulnerable group, then this would have to be analyzed in the same way as other cases in which legitimate and well-intentioned business practices are found to cause significant collateral harm. Usually, the morally correct course of action will be to engage in individual or collective action (depending on whether the harm is caused individually or collectively) to abate the harm or, if this proves impossible, to discontinue the behavior that causes it.

In a pioneering article on price discrimination, Alexei Marcoux has argued that "the widely held view about the unfairness of price discrimination is untenable; fairness considerations incline either no more against or else strongly in favor of price discrimination, as against other pricing regimes" (Marcoux, 2006: 58). He argues that even if we accept the claim that there is an equal-treatment norm, price discrimination does not violate this norm. He reasonably contends that what the equal-treatment norm demands of sellers is for all buyers to be afforded equal welfare, or perhaps equal welfare diminution, and that this is not the case under a unitary price regime. "If buyers are subject to a unitary price and some buyers have 
higher reservation prices than others, it follows that those with higher reservation prices derive greater utility from their purchases than those with lower reservation prices.... Consequently, a unitary price affords unequal degrees of utility enhancement to buyers" (Marcoux, 2006: 61; emphasis in original). He concludes that "[i]f fairness demands that each buyer enjoy the same welfare from purchasing the same product, then some form of price discrimination (whether one that charges each his reservation price or another price that affords each the same degree of consumer surplus) is necessary to achieve fairness (Marcoux, 2006: 61; emphasis in original). Notice, however, that all of this is a conditional argument. As I will explain below, Marcoux never endorses the major premise of his argument.

Marcoux's argument is correct as far as it goes, but it is incomplete. In the first place, price discrimination is necessary to achieve equal welfare enhancement to all buyers provided the buyers have different reservation prices. If they have the same reservation price, then, provided there is an equal-treatment norm, fairness will require uniform pricing. An important class of cases in which all buyers are likely to have very similar if not identical reservation prices is where the benefit provided by a product is a cost reduction for the buyer, as happens when firms are offered the opportunity to substitute a component they use in their products with a new one that has the same functional characteristics as the old one but a lower installation cost. According to Marcoux's argument, if a seller of such product were to practice price discrimination, he would be acting unfairly, for if all buyers have the same reservation price, it follows that they derive the same utility from the product, and then the only way to ensure that all of them are afforded the same utility enhancement when buying the product would be to charge the same price to all. However, it will be argued below that there is nothing necessarily unfair in practicing price discrimination when selling such products. It is also important to notice that often, as far as the seller knows, there is no difference among the reservation prices of different customers. In such cases, it would seem to follow from Marcoux's argument that uniform pricing is a requirement of fairness. Therefore, a seller who decided to lower her prices - when, as far as she knows, the reservation price of the next customer may well be the same as that of the last-would be behaving unfairly, and this even if she had significant reasons of her own, unrelated to the reservation prices of potential buyers, to lower the prices she charges; think for, instance, of an airplane that is only 20 percent full twenty-four hours before takeoff, or of a merchant who has a sudden need for cash.

Also, if Marcoux's argument is correct, it would also follow that in the great majority of cases in which different buyers have different reservation prices, sellers using uniform pricing would be behaving unfairly. Does it now turn out that an "everyday low prices" policy is necessarily unfair? Most likely, Marcoux would not want to go as far as that. However, his argument for defending price discrimination would seem to commit him to this conclusion.

More importantly, it seems fundamentally wrong to make an argument about fairness in pricing depend on the buyer's reservation price. Along those lines, the more desperate the buyer happens to be, the higher the price the seller is justified in charging. In fact, perversely, it would follow that by not charging a very high 
price to a customer who finds himself in a situation of very special need, the seller would be behaving unfairly.

To be fair to Marcoux, as was intimated above, he never endorses the major premise of his argument, the equal-treatment norm. He introduces the equal-treatment norm as a claim that "inform[s] the view that price discrimination is unfair to some buyers as against others" (Marcoux, 2006: 59) and says things such as: "If price discrimination is unfair because it violates the equal treatment norm" (Marcoux, 2006: 60; emphasis added) and "If fairness demands that each buyer enjoy the same welfare from purchasing the same product" (Marcoux, 2006: 61; emphasis added). Therefore, his argument is best understood as an argument ad hominem against those who defend uniform pricing on that basis. As such, it succeeds.

The line of argument presented here is different. The core of it is that no good arguments have been provided in the literature on equality to support the position that an equal-treatment norm applies to commercial transactions, and, more specifically, to pricing issues, and that there are important considerations that argue against such a norm in this context. It follows that, provided that the prices charged do not offend against fairness on other grounds, sellers will not be acting unfairly when they practice price discrimination because they are at liberty to charge whatever prices are consistent with their own legitimate interests, provided always that they do not offend against fairness on those other grounds. ${ }^{6}$

It will be useful to start by showing the implausibility of a blanket condemnation of price discrimination, in all circumstances and under all guises. Consider a well-worn example: ${ }^{7}$

A young doctor in a developing country is looking for ways to establish a medical practice in the rural community in which she was born, but cannot find a way to make the practice economically viable. She can see, on average, 400 patients per month. So, in order to cover her costs of $\$ 4,000$ per month (which include her own very modest salary), she should charge, on average, at least $\$ 10$ per visit. However, most of the people in her community can afford to pay, at most, $\$ 5$ per visit. An economist friend suggests to her that she charge 90 percent of her patients only $\$ 5$ per visit, but charge $\$ 55$ per visit to the 10 percent of her patients who can afford to pay this amount. In this way, she would be able to cover all her costs and the rural practice would be viable.

Of course, the poor patients like this solution. The rich patients also like it: they would rather pay $\$ 55$ per visit than have to travel by bad roads to the nearest hospital $50 \mathrm{~km}$ away, and they also like the added bonus of having a doctor close at hand in case of an emergency. The doctor also is happy: this solution would allow her to practice medicine in her own community.

The example is contrived, but it illustrates a common situation. Whenever the available alternatives are only price discrimination or no product at all (and we saw above that such situations are very common in a modern economy), all those potential customers whose reservation price is above the price they are asked to pay will be better off under the price discrimination alternative. And, as we also saw above and happens in this example, price discrimination often does not result 
in extraordinary profits for the seller (competition takes care of that); it just makes the provision of the product economically feasible.

Is the fact that the patients in the above example pay different fees enough to make it wrong to adopt the solution suggested by the economist? That solution makes everybody better off than the alternative of not establishing the rural practice. The fee discrimination in no way indicates less concern or respect for anybody; it is simply a practical mechanism through which the villagers are able to secure something they all want to have (the availability of medical services in the community) by contributing in proportion to their ability. Moreover, the doctor is not making extraordinary profits; most probably she could make more money if she were to practice in a larger city. What is not to like about this solution?

\section{THE EQUAL-TREATMENT NORM AND PRICE DISCRIMINATION}

Nonetheless, some readers may be made uncomfortable by the fact that some patients, just because they are more prosperous, are being made to pay more than their neighbors for exactly the same service. Are they not failing to receive the equal treatment to which, in the judgment of some, they are entitled? As Krugman (2000) put it in an article he published shortly after the Amazon scandal, "[d]ynamic pricing is . . . undeniably unfair: some people pay more just because of who they are." While, given the scope of this article and the space available, there is no way to discuss in sufficient detail the complex and contested philosophical and political implications of the ideas of equality and discrimination, it is possible at least to provide some context.

It may be useful to start by confronting head on Krugman's contention, just quoted, to the effect that it is unfair to treat people differently "just because of who they are." It is to be feared that in this statement Krugman has spoken far too broadly. There are many situations in which it would seem appropriate to treat people differently on the basis of their personal characteristics, even if these characteristics are beyond their power to control. An example among many would be denying blind people a driving license (Boxill, 1992). ${ }^{8}$

In his article on price discrimination, Marcoux refers to Krugman's statement and articulates more formally its point by making reference to an equal-treatment norm. He does not offer any arguments to defend the existence of this norm; he just presents it as a claim that "inform[s] the view that price discrimination is unfair to some buyers as against others" (Marcoux 2006: 59). I have already pointed out that it is not apparent that he considers it a valid claim, as the strategy of his article is to argue that price discrimination does not violate the equal-treatment norm because equal treatment of buyers by sellers does not require a unitary price. Are there any strong arguments for the applicability of an equal-treatment norm to the pricing decisions of sellers in relation to those who buy similar products from them? It would not seem so.

To substantiate this contention, my strategy will be to examine different types of equality and to show that not all have the same appeal. Furthermore, those types of equality that have a more obvious appeal provide very little, if any, justification for 
the applicability of an equal-treatment norm to pricing decisions, while those that provide a stronger justification for such a norm have less appeal. ${ }^{9}$ I will also argue that the plausibility of an equal-treatment norm being applicable to the decisions of individuals and non-governmental bodies is significantly less than that of a similar norm being applicable to government decisions. Finally, some of the negative implications that would follow from defending the existence of such a norm in a business context will be highlighted.

Some ethicists think that equality is valuable only instrumentally, that is to say, that equality is not valuable in itself, but only in so far as it helps to promote or protect other conditions or values. Others believe that equality itself is intrinsically valuable. This distinction matters, for the implications of these two views of the value of equality for the defense of an equal-treatment norm in commercial transactions are very different.

For instance, many scholars think that achieving equality of status is a worthy social ideal (Anderson, 1999; Miller, 1998; Walzer, 1983). But valuing equality of status does not entail that one believes that an absence of differences of status is itself intrinsically valuable. In fact many value equality of status only instrumentally; their ultimate concern is to promote social relations characterized by inclusion and respect and to avoid the marginalization, oppression, and exploitation that they think typically occur in societies in which people are ordered in a hierarchical way according to their respective ranks. They argue that it often follows from such social arrangements that those in superior ranks feel entitled to control a larger share of resources, to treat with contempt and even violence those in inferior positions, and to exact services from them, while those in the inferior ranks tend to accept these attitudes of their superiors as justified (Walzer, 1983; Young, 1990). Something similar can be said of many of those who are concerned with inequalities of power (Scanlon, 2002); often their ultimate concern is not with power differentials themselves, but with the ability that these power differentials may give to some to dominate others.

The main types of equality to which significant numbers of people attach an instrumental value include legal and political equality, and equality of status, power, wealth, and income. Appreciation of the ultimate values served by many or all of these types of equality - and therefore support for at least a degree of equality in these areas-is widely shared. However, the connection between the reduction of these types of inequality and price discrimination is tenuous.

For instance, if one's concern is with status inequality and the evils that may follow from it, it is difficult to conceive how many of the examples of price discrimination mentioned above in this article might come to have a significant effect on the creation, maintenance, or erosion of the relevant social hierarchies. The same can be said in relation to inequality of wealth or income; the effect on such inequalities of stopping all instances of price discrimination would most likely be negligible. In fact, insofar as there is any such effect, it could well be negative because, as was indicated in the section on the insights from economics, price discrimination typically results in higher prices for less price-sensitive customers and lower prices for those who are more price-sensitive. As most often the former are the richer consumers, there are strong reasons to expect that, generally, price discrimination will have 
positive distributional effects. The usefulness of stopping price discrimination for the purpose of reducing legal or political inequalities or inequalities of power seems also highly doubtful, to say the least.

While very little support is provided for an equal-treatment norm in pricing decisions on the basis of a belief in the instrumental value of equality, intuitively it would appear easier to move from a belief in the intrinsic value of equality to support for such a norm. We will see soon that even this move is not free from significant obstacles, but let us consider briefly how problematic arguments for this intrinsic value are.

The positive argument in favor of the intrinsic value of equality to which reference is most often made in the contemporary literature was popularized by Rawls. He argued that the natural and social circumstances that influence welfare, such as talent, education and environment, are not deserved and therefore the differences in welfare that result from them are morally arbitrary (Rawls, 1971). Accordingly, it would be better if such undeserved differences in welfare did not exist or at least were corrected to the extent possible. Many have followed him in this line of argument (e.g., Cohen, 1989; Dworkin, 1981; Nagel, 1991). However, the cogency of this argument is doubtful. Nozick (1974) has pointed out that it assumes that inequalities need justification; the argument takes for granted that there is a presumption against permitting inequalities as, in the absence of such assumption, nothing would follow from the fact that that there are no reasons for or against them; certainly, that lack of reasons would provide no justification to infringe on anyone's rights. ${ }^{10}$

The challenge that defenders of the intrinsic value of equality have to meet can be better appreciated if we consider equality without the distraction that may be created by the possible effect of equality on other matters. One way to accomplish this is to think of equality between two completely separated communities. We can imagine, to use an example discussed by Parfit (1998), a world in which there are only two communities, one in Africa and the other in America; the two are fully separated. What occurs in one has no effect whatsoever on the other. Let us also imagine that the two of them have more than enough resources to provide a good life to all their members. The community in America has a well-being score of 200 (assuming for the purpose of our argument that this statement makes sense), which indicates a very good life. The community in Africa is even better off, and has a well-being score of 205. Holding that equality is intrinsically valuable commits one to hold that there is something wrong with that world, a position that is less than obvious to many people.

Strong arguments have been put forward against the intrinsic value of equality. The two most prominent ones are the Argument from Incommensurability and the Leveling Down Objection. The Argument from Incommensurability basically objects that the different aspects of human wellbeing (e.g., knowledge and health) and the different ways of life (e.g., those of politicians, scholars, and full-time homemakers) are ultimately incommensurable. This poses an insurmountable problem to egalitarianism, as very often there will be no non-arbitrary way to decide whether or not there is an inequality in wellbeing between two human beings or two communities (Finnis, 1980; Raz, 1986). 
The Leveling Down Objection has been raised by philosophers like Nozick (1974), Raz (1986), and Parfit (2000). A version of the objection asks us to consider increasing equality in the two-communities-world just referred to by reducing the welfare of the Africans to a level of 200 that would bring them on a par with the Americans. Those raising the objection make the point that there is no reason at all to reduce the welfare of the Africans as this will make them worse off while not benefitting the Americans in any way (in the world of our example, they are not even aware of the existence of the Africans) and that this shows that equality is only desirable instrumentally, insofar as it brings about other valuable objectives, not intrinsically. ${ }^{11}$

Many distinguished philosophers of widely differing persuasions, such as Nozick (1974), Finnis (1980), Walzer (1983), Raz (1986), Frankfurt (1997), Parfit (1998), Anderson (1999), and Crisp (2003) have been moved by these and similar arguments to express doubts that equality is something intrinsically valuable. ${ }^{12}$ In different ways they have contended that we should not strive for equality in itself, but for objectives that advance human fulfillment, such as health, justice, and knowledge, and for the resources needed to attain these objectives. If some people are hungry, they should be helped because being hungry is not a proper situation for humans to be in, and not because of how their situation compares to that of other people. When that is done, it will often turn out that there is now greater equality compared to the previous state of affairs; still, what is valuable after a hungry person has been fed is not that there is now greater equality, but that there is greater satisfaction of human needs. As Raz has said:

[W]hat makes us care about various inequalities is not the inequality but the concern identified by the underlying [source of value]. It is the hunger of the hungry, the need of the needy, the suffering of the ill, and so on. The fact that they are worse off in the relevant respect than their neighbours is relevant. But it is relevant not as an independent evil of inequality. Its relevance is in showing that their hunger is greater, their need more pressing, their suffering more hurtful, and therefore our concern for the hungry, the needy, the suffering, and not our concern for equality, makes us give them the priority. (Raz, 1986: 240)

This is not to say that the value of equality has no defenders. Perhaps the most prominent of them is Larry Temkin. He is unequivocal in defending the intrinsic value of equality against objections (Temkin, 1993, 2000, 2003). It is significant for our purposes here, however, that even Temkin's conclusions on this issue-and in this he is representative of other equalitarians-do not translate directly into unqualified support for an equal-treatment norm being applied irrespective of the cost. Thus, for instance, he readily grants that the reasons we have to promote equality may be outweighed by other reasons (Temkin, 2003). His position in this respect is perhaps best summarized by the statement he often repeats: "Equality is not all that matters. But it matters some" (Temkin, 2000: 155).

Whatever one's position may be in relation to the value of equality and its relation to an equal-treatment norm, one still has to consider who should have the responsibility to provide equal treatment under such a norm. This matters because there is much more support—and there are better arguments—-for an equal-treatment norm in regard to the actions of the community or the state than in relation to the actions 
of individuals and non-government associations. Among the scholars who consider this problem specifically, Rawls makes it clear that his difference principle applies only to the major social and economic institutions, and that individuals and nonpolitical voluntary associations, such as businesses, should be left free to pursue their permissible ends within the structure the difference principle provides (Rawls, 1971: 1993). Scanlon states that even a prima facie duty to promote individually the equal welfare of all is not plausible (Scanlon, 2002); and Dworkin states specifically that it is the government that must show equal concern for the life of each citizen (Dworkin, 2000).

There are strong reasons in favour of so restricting an equal-treatment norm. In assessing whether or not justice demands that some people should sacrifice their interests for the benefit of others, we should be sensitive not only to the importance of the benefits some will receive, but also to the burdens that those who sacrifice will be called to shoulder. If individuals in all their actions were to be placed under the restrictions deriving from an equal-treatment norm, the burden would be very onerous indeed. As Cohen, a strong egalitarian who defends a wide-ranging and demanding egalitarianism, has said, "only an extreme moral rigorist could deny that every person has a right to pursue self-interest to some reasonable extent" (Cohen, 2000: 206; italics in original). He also makes the point that doing so does not have to be selfish: advancing this self-interest need not mean self-indulgence, it may involve the pursuit of special responsibilities, such as the care for relatives or the discharge of religious obligations. Another important reason not to extend the equal-treatment norm to individuals is that doing so would assume that they had adequate information about the impact and ramifications of their individual decisions. Rawls has argued that this would burden individuals with requirements of knowledge and foresight that often they will be unable to meet (Rawls, 1993). ${ }^{13}$

Likely due to considerations such as these, there is no support in the literature for the existence of a duty of individuals or non-government associations to treat all equally in their actions. The proposal that goes furthest in the direction of demanding that individuals factor equality considerations in their individual economic decisions is that of Cohen, who argues that individuals must take into account the effect of their actions on the worst off. Even this proposal has been subjected to strong qualifications by those who have commented on it (Pogge, 2000; Williams, 1998). In relation to the concrete issue of price discrimination, it is important to note that if individual economic units were to be obliged to promote equality by refraining from practicing price discrimination, this would require them to sacrifice very significant interests of their own. As we have seen above, one of the main conclusions of the economic study of price discrimination is that in many real-life circumstances, business actors need the liberty to engage in differential pricing in order to achieve an optimal allocation of resources and, in many cases, even to remain as viable business actors.

What conclusions can be drawn from the preceding discussion for the specific issue that concerns us here? I have argued that the wide agreement that exists on the instrumental value of some kinds of equality provides very little support for an equal-treatment norm in the realm of commercial transactions because significant 
intrusion in the activities of businesspeople and in their ability to pursue otherwise perfectly legitimate interests would have to be countenanced in order to achieve at best very modest improvements in these types of equality. I have also argued that while a belief in the intrinsic value of equality would provide a more direct support for such a norm, that intrinsic value is much more problematic, and many philosophers deny the intrinsic value of equality. Even in the case of philosophers who support it, their position does not necessarily imply support for an equal-treatment norm without qualifications and whatever the cost. I have also pointed out that egalitarian ethicists have advocated governmental action in order to promote whatever type of equality they favour. In fact, most of those who have considered the possibility of there being an individual duty to promote equality have explicitly excluded the existence of such a duty. At the level of individual action, the most that has been argued for in the direction of equality is the existence of a duty to take into account in our individual choices their impact on the worst-off; never, to the best of my knowledge, a strict equal-treatment norm.

My overall conclusion from all of this is that, fully recognizing that the debate on equality is ongoing and that few conclusions have yet received widespread agreement, the existence of an equal-treatment norm in regard to commercial transactions generally, and more specifically to pricing decisions, has, in the current state of the scholarly discussion, very little plausibility.

Beyond all of this, it may be useful to try to articulate in positive terms the position that it is misguided to claim the existence of an equal-treatment norm wide enough and strong enough to make it possible to derive directly from it the conclusion that a businessman has a strict duty to treat all his customers equally in his pricing decisions, even if this demands sacrificing important interests of his own. Consider the implications of claiming that one is entitled to be as well treated as everybody else, in all matters and by everybody, as a putative strong equal-treatment norm applicable to individuals would require. In some respects (notably in relation to the respect accorded to me and the political rights I enjoy) I am so entitled. But in other matters I simply recognize that you can and do have stronger commitments and responsibilities toward other people than toward me and therefore you are going to pay greater attention to their interests than to mine. I do not find it difficult to grant this as, in order to deny it fairly, I would also have to deny myself the freedom to differentiate my commitments and responsibilities toward different people and to treat them differently. At this point—and we are here very near rock bottom—all I can add is that, as far as I can see, a world in which I could in no way pay greater attention to the interests of those who are especially near and dear to me, and in which the very fact of having some people who are especially near and dear would already constitute an offence to others, does not attract me at all. It is not plausible to claim that I am under a duty to treat others equally, that I do not have what Scheffler (2001) calls an "agent-centered prerogative."

Some could argue that while a strict equal-treatment norm that would apply to all actions and commitments of individuals has very little plausibility, perhaps an equal-treatment norm with a narrower scope could be justified. Thus, perhaps one could justify an equal-treatment norm that would apply only to classes rather than to 
individuals. and only to economic relations rather than to personal matters. Perhaps a norm with that scope could be justified, but if there is no strict equal-treatment norm that applies to all actions and commitments of individuals, it is difficult to imagine what that justification would look like. The actual attempts to apply an equal-treatment norm to commercial transactions-whether elaborate ones like that of Marcoux (even if he argues only hypothetically), or summary ones like that of Krugman - appeal to an unqualified equal-treatment norm; it is this type of norm against which the arguments of this section have been directed. In view of the considerations set out above about the special problems of an equal-treatment norm that would apply to commercial transactions, it is doubtful that an attempt to justify a narrower-scope equal-treatment norm could be anything else than an ad hoc attempt to argue to a predetermined conclusion.

In this section, we have considered reasons for thinking that extreme equal treatment is not justified. In the process, we have shed light on the intuitive judgment that the arrangement proposed to the rural doctor by her economist friend in the earlier example is not objectionable. It follows that those who share that judgment cannot automatically consider all instances of price discrimination wrong. At least in those cases in which the available alternatives are only either price discrimination or no product at all, and price discrimination does not result in extraordinary profits to the producer, price discrimination is not in any way unethical.

At this point in the argument, some readers may have noticed a parallel between the discussion presented here of the example of the rural doctor and some discussions of exploitation that can be found in the literature. As we have seen, in the case of the rural doctor and in many parallel real-life situations, even the "victims" of price discrimination will be better off with it than they would be without it. Similarly, in some very interesting articles on exploitation in sweatshops and price gouging, Zwolinski (2007 and 2008) has argued that even if such practices are exploitative, they still advance the interests of their putative victims, who are better off by engaging in such transactions than if no transaction at all had taken place and, furthermore, that in some instances, the only alternative to the victims being beneficially exploited could well be that of no-transaction.

The parallel is enlightening, but it could also be misleading. Zwolinski is following Wertheimer's account of exploitation (Wertheimer, 1996) at least insofar as he agrees that exploitation is a moralized concept. That is, a necessary condition of exploitation is that the exploitee be treated unfairly. The parallel enlightens because both Wertheimer and Zwolinski accept that there can be cases of mutually beneficial exploitation. But it could also be misleading if the reader were to fail to note that the crux of the argument presented here is that price discrimination, taken in itself, is not unfair at all and therefore cannot be exploitative. If this argument were to be found wanting, and therefore it were to turn out that price discrimination is an exploitative practice, it would still in many cases be exploitation of the mutually beneficial variety. In a way similar to Zwolinski's argument regarding sweatshops and price gouging, this would have some important consequences for how strongly the practice should be censured and for the type of public policy measures that would be appropriate to deal with it. 


\section{RELAXING THE CONDITIONS}

What then of those instances of price discrimination that cannot be justified on the basis that they are necessary, even if only to some extent, in order to make the provision of some product or service possible and in which, moreover, the producer gets above-average rates of return? Are these not obvious instances of unfairness?

As it was pointed out in the discussion of the economics of price discrimination, sellers can only engage in price discrimination if they have a measure of monopoly power. In marketing terms, they must offer a product that is differentiated to some extent. In a mature economy in which there exist institutional arrangements to promote and protect competition, normally this will be the result of innovation, at least relative to what is available in a given market. The issue we are now facing can be highlighted with the following scenario: Imagine a firm that, as a result of innovation in some aspect of its business, enjoys for the time being some degree of pricing power. Imagine further that that business could be profitable, even very profitable, by selling its product at a uniform price. However, in order to be even more profitable, it is considering charging some of its customers a higher price than that it charges others. Is there anything unethical in this?

In order to make the issue more concrete, consider the following fanciful example:

A firm has just developed a product that increases a car's mileage, saving \$120 in gasoline per can of the product. Initially the product will be marketed only in Florida and California. The Chief Marketing Officer has recommended to the $\mathrm{CEO}$ a retail price of $\$ 60$ per can for Florida and $\$ 75$ per can for California. The reason for the difference in prices is that market research indicates that Californians are more eager to try new products and more willing to pay for them. Research indicates that at those prices, significant volumes of the product can be sold quite profitably in the two markets.

The firm in the scenario could be quite profitable if it were to charge a uniform price of $\$ 60$ per can of the product, and even if the product were to be sold only in either California or Florida. Therefore, the scenario is not the type of situation for which I have already argued that price discrimination will be unobjectionable. Now, assuming that the plan proposed by the Chief Marketing Officer makes sense from the perspective of optimizing returns to the firm, would there be any ethical reason for the CEO to insist in charging the same prices for the product in California and Florida?

I have argued at some length elsewhere that it would not be unethical to sell the product at $\$ 75$ or even $\$ 119$ per can (though the latter most likely would not be wise from a marketing point of view) (Elegido, 2009). Therefore I will address here only the issue of price discrimination, even though, as I indicated above, some ethicists have suggested other theories of justice in pricing.

It may be helpful if before trying to answer the question posed by the preceding scenario, we consider another one:

Imagine that currently the exchange rate of euros to US dollars is 1.4. Today is A's birthday and, being in a good mood, he offers to sell to somebody a $€ 10$ 
bill for only $\$ 5$. To a second person, he offers a $€ 10$ bill for $\$ 7$, and to a third one a $€ 10$ bill for $\$ 10$. All three are familiar with current exchange rates, and they accept happily.

Are these exchanges unethical? Has A wronged any of these people in any way? It would seem that the answer to these questions is clearly negative. In fact, what A has done is to make gifts of $\$ 9$ (to the first buyer), $\$ 7$ (to the second one), and $\$ 4$ (to the third). Granted, he has not given the same gift to each of them, but is he not free to make differences in the gifts he gives? The main reasons offered above against the applicability of an equal-treatment norm to pricing decisions would seem applicable also to gift-making decisions.

In Matthew's Gospel, Jesus tells the parable of the householder who goes out to hire laborers for his vineyard. Some of them he hires early in the day, and agrees to pay them a denarius a day. He keeps hiring groups of laborers at later times in the day, at the third, sixth, ninth, and eleventh hours. When the time comes to pay them, those who have worked least get a denarius. The ones who have worked since early in the day expected to get more, but also receive a denarius, and they complain. The parable concludes with the householder addressing one of the disappointed workers: "Friend, I am doing you no wrong; did you not agree with me for a denarius? Take what belongs to you and go; I choose to give to this last as I give to you. Am I not allowed to do what I choose with what belongs to me? Or do you begrudge my generosity?" (Matthew 20:13-15, RSV).

This text is not put forward here as a religious authority for the view that "salary discrimination" (i.e., "price-of-labor discrimination") is ethically acceptable. Most exegetes agree that each of the parables in the Gospels typically tries to make a very specific point and should not be taken to be arguing for any other positions depicted or implied in it. Here it is enough to notice how the narrative ends by making the point-as something so clear that it should clinch the argument without need for further explanation - that once the householder has paid the proper salary (the "price" of their labor) to each of the workers, he is free to be more generous to some of them without having to offer any explanations for his conduct.

In this light, the point of the $€ 10$ bills scenario is that, insofar as somebody gets more than commensurate value for the amount she pays, the fact that somebody else gets an even better deal does not mean that the first recipient is being wronged. If the person who gets the "less good" deal complains, the seller can always retort: "I have given you good value for your money; what is it to you if I decided to give an even better deal to somebody else?" If this line of argument is correct in relation to the $€ 10$ bills, it should also apply to the scenario of the gasoline additive. Also there, if the Californians are getting a good deal, as they undoubtedly are, they should have no business complaining that the Floridians are getting an even better one. Of course, all of us can sympathize with somebody who feels the pangs of envy; after all, we have all been there. But this is no reason for agreeing with that person once we have had the opportunity to consider the matter critically.

The above scenarios make the point effectively because in both of them the value of the product is clear, which makes it easy for us to see that in both cases 
the exchanges give good value for money. The issue of what is the value of most products or services is more complex and there is no way to do justice to it here as a subsidiary topic in this article. Elsewhere, I have concluded that the best indicator of the value in a given community for a differentiated product or service is the price it can fetch in an open market (Elegido, 1996, 2009).

At this point, it could be objected that even if the landlord in the parable (and similarly the person offering $€ 10$ bills at very favorable rates and the firm selling the gasoline additive) has a liberty-right to give a better deal to some than to others without having to offer explanations for their behavior, acting arbitrarily by giving a very good deal to some and a deal that is less good to others, without having any reasons for this difference in treatment, would not seem to be morally praiseworthy or even morally acceptable. This is true enough and it is not the purpose of this article to present an argument in favor of random action. The main point of the examples is that in those exchanges everybody has received appropriate value in exchange for the value they provided. In commercial exchanges, typically, the rational motivation for charging different prices to different customers will be that, as was shown in the section on the insights from economics, either that strategy is necessary for the firm to be able to offer at all a certain product or service, or even to survive; or at least that price discrimination leads to enhanced returns for the firm. Obviously, a behavior shaped by these goals is not arbitrary and the point of the examples is that it will not be unfair either.

In order not to give to this defense of price discrimination a wider scope than intended, it is important to remember at this point that this section opened by situating the discussion in relation to firms that have obtained a degree of pricing power through innovation. As was pointed out in the discussion of the economic understanding of price discrimination, in the absence of a degree of pricing power, price discrimination is simply impossible. But pricing power can be obtained also in other ways, not only by being innovative. If a given country does not have sound competition legislation, or the legislation is not enforced aggressively enough, there will be ways for business organizations to gain monopoly power in markets in which perhaps there obtained before a degree of competition. A strategy of winning monopoly power in such a situation and then proceeding to apply a policy of price discrimination as a way, perhaps among others, of extracting higher prices from some segments of the market would be ethically suspect in many ways and nothing said in this article would justify it.

\section{DELIBERATE REDUCTION OF QUALITY}

As was explained above, many cases of price discrimination involve offering different versions of a product or service. Versioning, as this practice is called, often involves making the cheaper versions of the product worse than they could be in order to encourage as many potential customers as possible to opt for the more expensive alternatives.

Thus, the main reason why paperback editions of books come to the market six months or one year later than the hardback version is to ensure that as many people 
as possible among those who are eager to buy that book purchase the hardback version, which is more profitable for the publisher. Shapiro and Varian (1998) speak in this context of the creation of "value-subtracted versions" and offer the example of two IBM printers, which were identical in all ways, except for the fact that one could print ten pages per minute while the other could print only five pages per minute. As would be expected, the faster printer sold at a significantly higher price. The interesting point is that the difference in performance was achieved by adding a special chip to the cheaper model in order to slow down its operation. As they observe, "because the subtraction of value required the manufacture and installation of a special chip, the low-priced version actually cost more to produce than the high-priced one" (Shapiro \& Varian, 1998: 112).

Railways were already using similar tactics by the middle of the nineteenth century. As J. Dupuit wrote over 160 years ago:

It is not because of the few thousand francs which would have to be spent to put a roof over the third-class carriages or to upholster the third-class seats that some company or other has open carriages with wooden benches. What the company is striving to do is to prevent the passengers who can pay the second class fare from travelling third class; it hits the poor, not because it wants to hurt them, but to frighten the rich. And it is again for the same reason that the companies having proved almost cruel to the third-class passengers and mean to the second-class ones, become lavish in dealing with first-class passengers. Having refused the poor what is necessary, they give the rich what is superfluous. (Dupuit, 1849; cited in Ekelund 1970)

I am sure that modern-day flyers have no difficulty grasping Dupuit's point.

Most people find the idea of deliberately reducing quality shocking. Is it not unethical intentionally giving customers a product worse than one could profitably give them? Before jumping to conclusions on this issue, let us remember that, as we observed when discussing the conclusions of economists on price discrimination, in the absence of price differentials it may often be impossible to make the product or service available at all; and that in other cases, by making larger the total pool of customers, price discrimination makes it possible to offer to all the customers a better and/or cheaper service.

There is an even more basic point to which we should address our attention. While many people will agree that sellers should engage in mutually beneficial relationships with their customers ("win-win" is the popular term), it would be very difficult to argue that they have a positive obligation to give their customers the very best deal possible, or even that they have to attain a certain level of quality that is technically possible for them to attain and for which there is sufficient demand, at prices that cover the firm's costs. I have argued elsewhere that the minimum level below which a firm cannot go in its exchanges with its customers without being unfair to them is that of mutuality of benefits for firm and customers, and that the appropriate standard of measure for the benefit to each of the parties is the price of that benefit in an open market (Elegido, 1998, 2009). Others have suggested different standards, and I will not repeat here the arguments I have offered elsewhere for my own position. The important point is that all available standards set a minimum 
threshold as a requirement of fairness; none requires that the sellers do the best they can, even subject to some constraints. It is likely that the reason this is so is that giving a better deal typically necessitates that the sellers increase their own costs, and therefore sacrifice, to a certain extent, other legitimate interests, such as being able to offer their products (or better or cheaper products) to other customers, being able to get a profit commensurate with the value they create for customers, being able to offer better salaries (or more secure or stable employment) to their employees, and so on. It is obviously difficult to offer cogent arguments of a general character to justify why there should be a general duty to sacrifice such legitimate interests after the minimum floor of the applicable standard of fairness has been attained. Thus, it will not be unfair to deliberately provide a lower quality than one could, as, for instance, by bringing out the paperback version of a new book six months after the hardback version, when one could equally well bring it out after only four months, if this will enable the seller to satisfy better some of the other legitimate interests for which she is also responsible.

This is not to say that customers should always be given the barest minimum compatible with the correct standard of fairness and with the promotion of the long-term interests of the firm. That would be so in the view of shareholder value maximizers, but even in this case, such position derives from their view about the responsibilities of the managers of the firm toward its owners, not from the requirements of fairness in exchanges. For any other decision makers, many other considerations will come into play at this point. In many cases, it may turn out that, all in all, there are very good reasons for giving a better service to one's customers and that it will be possible to do this without sacrificing to an inappropriate extent any legitimate interests of other stakeholders. Therefore, the decision maker will conclude that it will be better not to reduce quality as much as might be consistent with carrying out the most profitable scheme of price discrimination available. The point is that voluntarily reducing quality in some versions of a product to the extent required by effective price discrimination is not unfair in itself as long as the correct standard of price fairness is upheld, not that the seller must always reduce quality.

\section{CONCLUSIONS}

The implications of the preceding analyses may perhaps become clearer through one last example:

You arrive in a city late at night and check into a hotel, at which time you are informed that the rate per night is $\$ 300$. You find it steep, but it is late, you are tired, and outside it is raining heavily, so you accept and move into your room. The following morning, while having breakfast, you strike up a casual conversation with a fellow guest and learn that she had made her reservation online and is only paying $\$ 80$ per night.

Would you be justified in feeling wronged by the hotel? Going by the standard defended in this article, it depends. If $\$ 300$ per night is an unfair price for that room, you would have been taken advantage of. Of course, the controversial point here is 
how to determine whether $\$ 300$ per night is a fair price for the room. I believe the key test is whether a substantial proportion of the hotel guests pay that rate. If they do, that would tend to show that many people think that $\$ 300$ per night is worth paying for the service the hotel offers and that would be a very good indication that that is actually the case. In my view, we do not have a better one. But, as I have not argued for this position here, I am willing to leave this issue open. You perhaps believe that another one among the theories of fair pricing referred to at the beginning of this article, or any other not mentioned there, is correct; or even that there is no such a thing as a fair price. My point is that a guest will only be justified in feeling wronged by the hotel if the price, considered in itself, happens to be unfair, according to whichever test has to be applied to determine this.

On the other hand, if $\$ 300$ per night is a fair price for the room, the situation will be appropriately described by saying that the hotel, in offering discounted rates to many guests, has only responded to the characteristics of its market and its competitive environment; the way in which it does so does not imply in any way disrespect or lack of concern for you; and in no way do they take advantage of you as the rate they charge you, considered in itself, is not unfair. It will still be understandable if you feel unhappy about the experience, but the type of unhappiness appropriate in this situation will be that of someone who has realized that he could have been a smarter customer (and who perhaps now resolves to look more carefully in future for available discounts) rather than the unhappiness of the person who has been wronged.

The overall conclusion I draw from the arguments offered in this article is that, ultimately, there is no independent ethics of price discrimination. Provided that the price a buyer pays is not wrong according to the appropriate standard of fairness, that price will not be unjust (although the overall transaction might be objectionable in some other ways, such as being deceptive or expressing lack of respect). Whether or not there is price discrimination is, in itself, simply irrelevant to the justice of a price.

\section{NOTES}

The author thanks Denis Arnold, associate editor of this journal, and three anonymous referees for their painstaking help, which has contributed to significantly improve the quality of this article.

1. An example of the way in which the unethical nature of price discrimination is routinely taken for granted is provided by the well-known marketing textbook of Pride and Ferrel (2010). Introducing the chapter devoted to "Environmental Forces, Social Responsibility, and Ethics," it states: "[S]ome companies engage in activities that customers, other marketers, and society in general deem unacceptable. Such activities include questionable selling practices, bribery, price discrimination, deceptive advertising, misleading packaging, and marketing deceptive products" (Pride \& Ferrel, 2010: 94; italics added).

2. I thank a reviewer for this way of formulating the issue.

3. Wertheimer has argued that, at least for a range of cases, a hypothetical market price-the price that would be generated by a competitive market — provides the standard for a fair transaction (Wertheimer, 1996). Michel (1999) holds that the only requirement for a price to be just is that it be agreed upon in the course of a voluntary transaction, and that the only conditions necessary for a transaction to be voluntary are that none of the parties use or threaten physical violence toward the other or engage in deception. Others have proposed different standards, but without attempting to provide a justification for their positions nor elaborating them in detail. Frank proposes that, with some qualifications, a fair transaction is one in which the difference between the buyer's and seller's reservation prices is divided (approximately) equally; the transaction becomes increasingly unfair as the division increasingly deviates from equality (Frank, 1988). 
Snyder, building on the work of Sample (2003), suggests that "micro fairness" standards must be supplemented with "macro fairness" standards that attempt to correct for the effect of structural injustice on the bargaining power of parties to a transaction. In his account, a macro fairness standard also imagines a hypothetical exchange between the parties in order to establish a baseline against which fairness can be measured, but in doing so, it is not restricted to a consideration of what could result from a competitive market, but makes corrections for the impact of factors of structural injustice, such as, for instance, that some workers may be earning less than a living wage, or that some borrowers may be cut off from alternative and less expensive sources of finance because of systematic racism (Snyder, 2010). Zwolinski suggests that "[t]o determine whether a mutually beneficial exchange is exploitative we must compare the gains made by the parties ... to the baseline in which each party acts within their rights with respect to the other, and ensure that parties are left at least as well off as they would be under those circumstances" (Zwolinski 2007: 706). Valdman argues that a non-exploitative price is one that "falls into a range bounded by the lowest amount that a seller would accept and the highest amount that a buyer would pay if both were informed and if neither had unacceptable non-transaction costs" (Valdman, 2009: 12).

4. A reviewer has raised the point that strictly speaking it is not true that the fairness of price discrimination is independent of the substantive theory of price fairness one may hold. If fairness required that the price for which a product is sold were based on the cost of manufacturing and distributing it (presumably allowing for a "reasonable" profit), then there would be no room left for fair price discrimination. But this is not so. If a "reasonable profit" is defined in terms of a range of profit margins (it could be defined in any other way without affecting the argument) as, say, 5-15 percent, it will be possible to practice price discrimination while fulfilling the requirements of this conception of price fairness. Even if the reasonable profit margin is defined in very specific terms (say 7 percent) it will still be possible to get a 7 percent margin in one transaction and less than 7 percent in another.

5. Some could argue that even if price discrimination were used to convey contempt or dislike for the members of a group, it would still not be unethical as this is a market transaction and the buyer has the option to walk away from it. But ignoring an insult does not make it disappear or make its utterance ethical. Imagine that members of an ethnic group are required to sit in a worse part of a restaurant and to use less well-kept restrooms. Even if all the members of that ethnic group chose not to make use of all such restaurants, the mere existence of this policy would be an insult to them.

6. Other grounds on which specific cases of price discrimination could "offend against fairness" include making it a vehicle for expressing contempt or dislike for some individual or groups, practicing it even though in a given case it worsens the plight of a vulnerable group, using it to injure competition by giving one or more buyers a competitive advantage over other buyers, and charging some buyers (though not all) a price that exceeds a fair level (however ultimately this fair level be defined).

7. See, for instance, Varian (2000), Rakowski (2004), and Odlyzko (2004a).

8. Krugman did not make that statement in a scholarly publication, and therefore it is most likely unfair to fault him for not speaking with an accuracy that is not called for in the medium he used.

9. It is very difficult to discuss briefly the scholarly literature on equality. A main reason for this is that there are many different theories of equality. An important issue that divides these theories is what should be the subject matter of equality, what Amartya Sen (1980) has referred to as the "Equality of What?" question. The issues on which different theories concentrate include (most often in opposition to each other) resources, welfare, opportunity for welfare, wellbeing, real freedom, access to advantage, and capabilities, among others. To further complicate matters, there are many hybrid theories that combine two or more of these elements. Another fundamental issue dividing theories of equality is that of the subjects of equality. Important questions here are whether equality should apply to groups or individuals; whether the ideal of equality applies only within communities or also between them; and whether, as some have argued, nonhuman animals should also be considered.

10. Nagel (2002; first published in 1977) endorses the force of this argument as against Rawls. Cohen (2000) states that even though he is "in sympathy with . . . the argument, I also have reservations about it. Rawls's use of the motif of moral arbitrariness is subjected to (as yet) largely unanswered searching criticism by Robert Nozick in his Anarchy, State, and Utopia."

11. Parfit (2000: 98) drives home vividly the point of the argument: "If inequality is bad, its disappearance must be in one way a change for the better, however this change occurs. Suppose that those who are better off suffer some misfortune, so that they become as badly off as everyone else. Since these events 
would remove the inequality, they must be in one way welcome ... even though they would be worse for some people, and better for no one."

The Raising Up Objection is similar in spirit and intention to the Leveling Down Objection. It argues that, similarly to how, according to the Leveling Down Objection, a situation is not improved in any way if the lot of some people is made worse without anybody's lot being made better, so also no situation is made worse in any way if the lot of some is made better without worsening the lot of anybody else, and this even if those whose lot is improved were already better off than anybody else (Doherty, 2008; Temkin, 2009). In both cases, the intention of the argument is to try to show that equality as such has no value and what matters is the wellbeing of individual agents.

12. There is wide agreement among philosophers that all human beings should be treated, in the expression of Dworkin (1977:370), with "equal concern and respect." Beyond this basic idea, there is also very general agreement that there should be equality in regard to fundamental legal rights and freedoms, to possibilities of political participation, and to social opportunity (Gosepath, 2009). By contrast, how far, if at all, equality of economic and social outcomes should be considered a worthy ideal, and whether, and to what extent, the state should take steps to establish it, remain keenly contested issues.

It is also useful to consult international legal documents, as they give some indication of the extent to which some normative ideas are shared. The existence of a right to freedom from discrimination is asserted in the Universal Declaration of Human Rights (1948) and in subsequent treaties, such as the International Convention on the Elimination of All Forms of Racial Discrimination (1965), the International Covenant on Civil and Political Rights (1966), and the Convention on the Elimination of All Forms of Discrimination Against Women (1979). However, in the context of fundamental human rights documents, the proscription of discrimination refers always to differential treatment in the enjoyment of basic rights, which is premised on a person being a member of some specific group (on the basis of race, sex, ethnicity, nationality, sexuality, religion, and so on), not to a general right to be treated equally.

13. Rawls offers as an example the relatively simple case of bequests: "It is obviously not sensible to impose on parents (as heads of families) the duty to adjust their own bequests to what they estimate the effects of the totality of actual bequests will be on the next generation, much less beyond" (Rawls, 1993: 267).

\section{REFERENCES}

Ambrose, D. 1979. Retail grocery pricing: Inner-city, suburban, and rural comparisons. Journal of Business, 52: 95-102.

Anderson, E. 1999. What is the point of equality? Ethics, 109: 287-337.

Ayers, I. 1991. Fair driving: Gender and race discrimination in rental car negotiations. Harvard Law Review, 104(4): 817-72.

2001. Pervasive discrimination. Chicago: University of Chicago Press.

Ayers, I., \& Siegelman, P. 1995. Race and gender discrimination in bargaining for a new car. The American Economic Review, 85(3): 304-21.

Baker, C. E. 1994. Advertising and a democratic press. Princeton, NJ: Princeton University Press.

Baumol, W. J., \& Swanson, D. G. 2003. The new economy and ubiquitous competitive price discrimination: Identifying defensible criteria of market power. Antitrust Law Journal, 70(3): 661-85.

Boxill, B. 1992. Blacks and social justice (revised ed.). Lanham, MD: Rowman and Littlefield.

Campbell, M. C. 1999. Why did you do that? The important role of inferred motive in perceptions of price fairness. Journal of Product and Brand Management, 8: 145-52. 
Casale, J., Esola, L. \& Wojcik, J. 2007. iPhone price cut makes N.Y. woman irate. Business Insurance, 1(41): 68.

Chen, Y., Moorthy, S., \& Zhang, Z. J. 2005. Price discrimination after the purchase: Rebates as state-dependent discounts. Management Science, 51(7): 1131-40.

City of New York, Department of Consumer Affairs. 1992. Gypped by gender: A study of price bias against women in the marketplace.

Clerides, S. 2004. Book value: Inter-temporal pricing and quality discrimination in the U.S. markets for books. Economic Inquiry, 42: 402-12.

Cohen, G. A. 1989. On the currency of egalitarian justice. Ethics, 99: 906-44.

. 2000. If you're an egalitarian, how come you're so rich? Cambridge, MA: Harvard University Press

Crisp, R. 2003. Equality, priority and compassion. Ethics, 113(4): 745-63.

Doherty, J. M. 2008. Law in an elevator: When leveling down remedies let equality off in the basement. California Law Review, 81: 1017-65.

Dupuit, J. 1849. Annales des ponts et chausses, 17(2): 83-110. Translated as "On Tolls and Transport Charges," in International Economic Papers. London: Macmillan, 1952.

Dworkin, R. 1977. Taking rights seriously, Cambridge, MA: Harvard University Press. . 1981. What is equality? II. Equality of resources. Philosophy and Public Affairs, 10: 283-345.

. 2000. Sovereign virtue, Cambridge, MA: Harvard University Press.

Ekelund, R. B. 1970. Price discrimination and product differentiation in economic theory: An early analysis. Quarterly Journal of Economics, 84: 268-78.

Elegido, J. M. 1996. Fundamentals of business ethics: A developing country perspective. Ibadan: Spectrum Books.

1998. La Responsabilidad Básica de la Empresa hacia sus Clientes.” In D. Mele (Ed.), Etica en dirección comercial y publicidad: 87-101. Barcelona: Estudios y Ediciones IESE.

2009. The just price: Three insights from the Salamanca School. Journal of Business Ethics, 90: 29-46.

Finke, M., Chern, W. \& Fox, J. 1997. Do the urban poor pay more for food? Issues in measurement. Advancing the Consumer Interest, 9(1): 13-17.

Finnis, J. M. 1980. Natural law and natural rights, Oxford: Clarendon Press.

Frank, R. 2001. Prescription drug prices: Why do some pay more than others do?" Health Affairs, 20(2): 115-28.

Frank, R. H. 1988. Passions within reason: The strategic role of the emotions. New York: W. W. Norton.

2006. How much is that laptop? It depends on the color of the case. And that's fair. The New York Times (July 6).

Frankfurt, H. 1997. Equality and respect. Social Research, 64: 3-15. 
Gosepath, S. 2009 Equality. In Edward N. Zalta (Ed.), The Stanford Encyclopedia of Philosophy (Winter 2009 edition). http://plato.stanford.edu/archives/win2009/ entries/equality/.

Grewal, D., \& Compeau, L. D. 1999. Pricing and public policy: A research agenda and an overview of the special issue. Journal of Public Policy and Marketing, 18: 3-10.

Groom, P. 1966. Prices in poor neighborhoods. Monthly Labor Review, 89: 1085-90.

Hayes, L. R. 2000. Are prices higher for the poor in New York City? Journal of Consumer Policy, 23: 127-52.

Howell, J. 1991. Potential profitability and decreased consumer welfare through manufacturers' cents-off coupons. The Journal of Consumer Affairs, 25: 164-84.

Huang, M. 2005. Unequal pricing in the information economy: Implications for consumer welfare. Journal of Business Ethics, 56: 305-15.

Kahneman, D., Knetsch, J. L., \& Thaler, R. H. 1986. Faairness and the assumptions of economics. Journal of Business, 59(4), pt. 2: 285-300.

Krugman, P. 2000. What price fairness? The New York Times (October 4): A31.

Larkin, I. 2008. Bargains-then-ripoffs: Innovation, pricing and lock-in enterprise software. Best Paper Proceedings of the Academy of Management.

Levine, M. E. 2002. Price discrimination without market power. Yale Journal on Regulation, 19: 1-36.

Liston-Heyes, C., \& Neokleous, E. 2000. Gender-based pricing in the hairdressing industry. Journal of Consumer Policy, 23: 107-26.

Lott, J. R., Jr., \& Roberts, R. D. 1991. A guide to pitfalls of identifying price discrimination. Economic Inquiry, 29: 14-23.

Marcoux, A. M. 2006. Much ado about price discrimination. Journal of Markets and Morality, 9(1): 57-69.

McCartney, S. 2010. "Kennedy Pushed Airline Deregulation, Changed U.S. Air Travel." Wall Street Journal (August 26).

McPherson, M. S., \& Schapiro, M. O. 1998. The student aid game: Meeting need and rewarding talent in american higher education. Princeton, NJ: Princeton University Press.

McWilliams, G. 2001. Lean machine: How Dell fine-tunes its PC pricing to gain an edge in slow market. Wall Street Journal (June 8).

Michel, C. 1999. What is a 'just price'? Journal of Markets and Morality, 2(2): 182-96.

Miller, D. 1998. Equality and justice. In A. Mason (Ed.), Ideals of equality: 21-36. Oxford: Blackwell Publishers.

Mueller, C. E. 2004. Two varieties of price discrimination in 2004: Airline "targetting" versus Wal-Mart "blietzkrieg." Antitrust Law \& Economics Review, 32(3): 1-24.

Nagel, T. 1991. Equality and partiality. New York: Oxford University Press.

2002. Equality. In M. Clayton \& A. Williams (Eds.), The ideal of equality: 60-80. New York: Palgrave Macmillan.

Narasimhan, C. 1984. A price discrimination theory of coupons. Marketing Science, 3 (Spring): 128-47. 
Nozick, R. 1974. Anarchy, state, and utopia. New York: Basic Books.

Odlyzko, A. M. 2004a. Access to the literature: The debate continues. Nature Web Forum (March 25).

2004b. The evolution of price discrimination in transportation and its implications for the Internet. Review of Network Economics, 3(3): 323-46.

Parfit, D. 1998. Equality and priority. In A. Mason (Ed.), Ideals of equality: 1-20. Oxford: Basil Blackwell.

. 2000. Equality or priority. In M. Clayton and A. Williams (Eds.), The ideal of equality, 81-125. New York: St. Martin's Press.

Phlips, L. 1983. The economics of price discrimination. London: Cambridge University Press.

Pogge, T. 2000. On the site of distributive justice: Reflections on Cohen and Murphy. Philosophy \& Public Affairs, 29: 137-65.

Pride, W. M., \& Ferrell, O. C. 2010. Marketing. Mason, OH: South-Western Cengage Learning.

Rakowski, J. J. 2004. Does the consumer have an obligation to cooperate with price discrimination? Business Ethics Quarterly, 14: 263-74.

Raz, J. 1986. The morality of freedom. Oxford: Clarendon Press.

Rawls, J. 1971. A theory of justice. Cambridge, MA: Harvard university Press. 1993. Political liberalism. New York: Columbia University Press.

Rosenbaum, D. I., \& Ye, M. 1997. Price discrimination and economics journals. Applied Economics, 29: 1611-18.

Sample, R. J. 2003. Exploitation: What it is and why it is wrong. New York: Rowman and Littlefield.

Scanlon, T. M. 2002. The diversity of objections to inequality. In M. Clayton \& A. Williams (Eds.), The ideal of equality. New York: Palgrave MacMillan.

Scheffler, S. 2001. Boundaries and allegiances. Oxford: Oxford University Press.

Schmalensee, R. 1981. Output and welfare implications of monopolistic third-degree price discrimination. American Economic Review, 71: 242-47.

Schwartz, M. 1990. Third-degree price discrimination and output: Generalizing a welfare result. American Economic Review, 80: 1259-62.

Sen, A. 1980. Equality of what? In S. McMurrin (Ed.), The Tanner Lectures on Human Values, I. Cambridge: Cambridge University Press.

Shapiro, C., \& Varian, H. R. 1998. Versioning: The smart way to sell information. Harvard Business Review, 76(6): 106-14.

Sinha, I. 2000. Cost transparency: The net's real threat to prices and brands. Harvard Business Review, 78(2): 43-50.

Snyder, J. 2010. Exploitation and sweatshop labor: Perspectives and issues. Business Ethics Quarterly, 20: 187-213.

Stigler, G. 1987. A theory of price. New York: Macmillan. 
Stole, L. A. 2007. Price discrimination and competition. In M. Armstrong \& R. Porter (Eds.), Handbook of industrial organization, vol. 3. Amsterdan: Elsevier B.V.

Temkin, L.S. 1993. Inequality. New York: Oxford University Press.

2000. Equality, priority and the levelling down objection. In M. Clayton \& A. Williams (Eds.), The ideal of equality. New York: Palgrave MacMillan.

2003. Equality, priority or what? Economics and Philosophy, 19: 61-87.

2009. Illuminating egalitarianism. In T. Christiano \& J. P. Christman (Eds.), Contemporary debates in political philosophy. London: Blackwell.

Tirole, J. 1989. The theory of industrial organizationion. Cambridge, MA: MIT Press.

Turow, J. 2005. Have they got a deal for you. Washington Post (June 19): B01.

Valdman, M. 2009. A theory of wrongful exploitation. Philosophers' Imprint, 9(6): 1-14.

Varian, H. R. 1980. A model of sales. American Economic Review, 70: 651-59. (See also erratum: American Economic Review, 71: 517.)

1985. Price discrimination and social welfare. American Economic Review, 75: 870-75.

1992. Microeconomic analysis, 3rd ed. London: Norton.

1996. Differential pricing and efficiency. First Monday, 1(2).

1997. Versioning information goods. http://www, sims.b erkeley, edu/-. hal/ people/hal /papers.html/.

2000. A big factor in prescription drug pricing: Location, location, location. New York Times (September 21).

Vitell, S. J., Rawwas, M. Y. A., \& Festerband, T. A. 1991. The business ethics of pharmacists: conflicts, practices and beliefs. Journal of Business Ethics, 10: 295-301.

Walzer, M. 1983. Spheres of justice: A defence of pluralism and equality. New York: Basic Books.

Wertheimer, A. 1996. Exploitation. Princeton, NJ: Princeton University Press.

Williams, A. 1998. Incentives, inequalaity and publicity. Philosophy and Public Affairs, 27(3): 225-47.

Young, I. M. 1990. Justice and the politics of difference. Princeton, NJ: Princeton University Press.

Zwolinski, M. 2007. Sweatshops, choice, and exploitation. Business Ethics Quarterly, 17: 689-727. 2008. The ethics of price gouging. Business Ethics Quarterly, 18: 347-78. 